\title{
Retraction Note to: Stability and direction for a class of Schrödingerean difference equations with delay
}

\author{
Mingzhu Lai ${ }^{1}$, Jianguo Sun ${ }^{1 *}$ and Wei Li ${ }^{2}$
}

The original article can be found online at https://doi.org/10.1186/ s13662-017-1132-3

"Correspondence: jianguosun81@sina.cn

'Department of Computer Science and Technology, Harbin

Engineering University, Harbin, China

Full list of author information is available at the end of the article
The Editors-in-Chief have retracted this article [1] because it overlaps with articles by other authors that were simultaneously under consideration at different journals $[2,3]$. The article also shows evidence of authorship manipulation. Additionally, contrary to the statement in the Acknowledgements section that "The Schrödingerean manifold theorem in this paper was proved while the third author was at the Norwegian University of Science and Technology as a visiting scholar", the Norwegian University of Science and Technology confirmed that he has not been affiliated with their institution.

\section{Author details}

'Department of Computer Science and Technology, Harbin Engineering University, Harbin, China. ${ }^{2}$ Academic Affairs

Department, Guizhou City Vocational College, Guiyang, China.

\section{Publisher's Note}

Springer Nature remains neutral with regard to jurisdictional claims in published maps and institutional affiliations.

Published online: 28 April 2020

\section{References}

1. Lai, M., Sun, J., Li, W.: Stability and direction for a class of Schrödingerean difference equations with delay. Adv. Differ. Equ. 2017, 87 (2017). https://doi.org/10.1186/s13662-017-1132-3

2. Jiangang, Z., Jiarong, L., Wenju, D., Yandong, C., Hongwei, L.: Hopf bifurcation analysis and its preliminary control in a Hasting-Powell food chain model with two different delays. J. Nonlinear Sci. Appl. 10(8), 4181-4196 (2017)

3. Wang, J., Roncalver, H.: New applications of Schrödinger type inequalities to the existence and uniqueness of Schrödingerean equilibrium. J. Inequal. Appl. 2017, 61 (2017). https://doi.org/10.1186/s13660-017-1332-0

\section{Springer}

(c) The Author(s) 2020. This article is licensed under a Creative Commons Attribution 4.0 International License, which permits use, sharing, adaptation, distribution and reproduction in any medium or format, as long as you give appropriate credit to the original author(s) and the source, provide a link to the Creative Commons licence, and indicate if changes were made. The images or other third party material in this article are included in the article's Creative Commons licence, unless indicated otherwise in a credit line to the material. If material is not included in the article's Creative Commons licence and your intended use is not permitted by statutory regulation or exceeds the permitted use, you will need to obtain permission directly from the copyright holder. To view a copy of this licence, visit http://creativecommons.org/licenses/by/4.0/. 